\title{
Day Times Picomole per Milliliter
}

National Cancer Institute

\section{Source}

National Cancer Institute. Day Times Picomole per Milliliter. NCI Thesaurus. Code C85594.

Days times picomoles per milliliter. 